\title{
8
}

\section{LILY BRAYTON}

\section{A theatre maker in every sense}

\section{Brian Singleton}

Lily Brayton (1876-1953) is barely remembered today, overshadowed in historical accounts of British theatre history by her Australian-born husband, Oscar Asche, who penned the most commercially successful production on the London stage in the first half of the twentieth century (Chu Chin Chow, His Majesty's Theatre, 1916-21). Brayton was lead actress in most of the productions directed by Asche, and was generally regarded by contemporary critics as one of the best Shakespearean actresses of the early twentieth century. Despite her prominence in a succession of syndicated managements of His Majesty's Theatre from 1907 to 1922 with Asche, the in-built bias against women in the commercial and theatrical worlds in Edwardian England and afterwards meant that the visibility of her work in theatre production was masked by that of her husband. Onstage she may well have been known as actress Lily Brayton, but offstage and to the public, she performed the role of Mrs Oscar Asche.

Asche and Brayton followed in the footsteps of theatrical couples from the late Victorian period who became reputable actor-managers, and had to negotiate their marriage and their business in the context of what Tracy C. Davis refers to as 'gentlemanly capitalism' (Davis, 2000: 286). For Brayton this was even more precarious than was experienced by her Australian husband, as she had to perform her private role in the marriage in the very public realm of theatre both on and off the stage; as such, according to Davis, we might recognise actor-manageresses such as Brayton as 'iconoclasts or subalterns: publicly oriented women who claim the right to make representations - this is what theatre does, after all - yet who nevertheless in representations of them cannot be separated from either their marital state or their particular marriage 


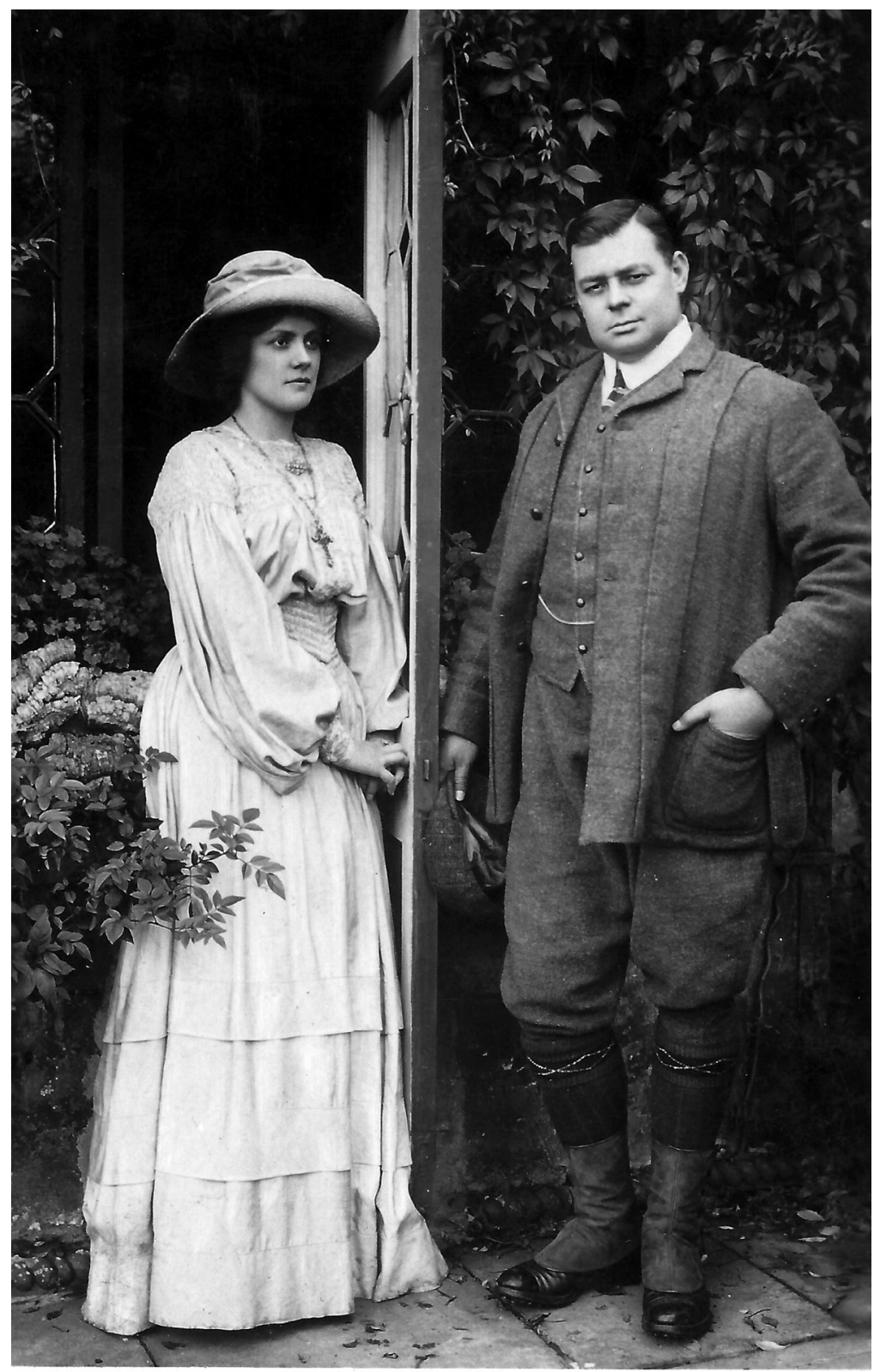

24 Lily Brayton and Oscar Asche offstage. 
partners' (2000: 286). This negotiation of self-presentation is also one of the reasons why Brayton is largely absent from history. While onstage she may have presented images of strong and clever women, and much of the time played those women opposite her husband, offstage it was Asche who spoke publicly on her behalf. ${ }^{1}$ As Veronica Kelly admits, 'Distinguishing Brayton's own input and achievements thus faces the problem of self-presentations produced by these stars as part of their successful public personae' (Kelly, 2006: 1). Further, the success of Brayton's onstage success, renowned and remembered as she was for her 'beauty', 2 also overshadows her contribution to the financing, management and production of theatre, for which her husband publicly took the credit. This essay follows on from Kelly's reclamation of Brayton as a theatre 'artist' while on the company's two tours to Australia (1909-10, 1912), by reading between her self-presentation on and off the British stage, and the evidence pertaining to the full extent of her 'labour' in the theatre.

Lily Brayton was born Elizabeth Brayton in 1876, the youngest of four daughters of Margaret Brayton, housewife, and John Grindall Brayton, physician and surgeon, in the burgeoning mill and coal-mining town of Hindley, near Wigan in Lancashire. ${ }^{3}$ In such an environment and at such a time, acting as a profession for a doctor's daughter from the North of England would not have been considered suitable or respectable. However, like many other young women, Brayton took elocution lessons with Miss Morden Gray in Manchester, though less as a social attribute and more with an eye to a career. ${ }^{4}$ After her father's death in 1892, she defied her parents' wishes to keep her off the stage, and wrote to the notable Shakespearean actor-manager Frank Benson. ${ }^{5}$ Benson not only wrote back to her, but also granted her an interview while on tour to the Theatre Royal Manchester in 1896, and immediately hired her (Fletcher, 2004: 11). Margaret Brayton's dismay at Lily's chosen career was compounded when her younger daughter Agnes followed Lily into the profession. ${ }^{6}$ It was in F. R. Benson's Shakespearean Company that Lily learned her craft, graduating over the tours of Britain and Ireland to larger roles, and playing twenty-one Shakespearean women in fourteen plays over four seasons (from 1897) in Stratford alone. In Benson's company she met Oscar Asche. Almost six years her senior, ${ }^{7}$ with his athletic build and booming voice Asche was a rising star in Benson's company. Despite protests from her mother, Lily married Oscar in her family church of St Peter's in Hindley on 22 June 1898, one day shy of her 22nd birthday, with her sister Mary as bridesmaid and Oscar's friend and 
actor Harry Hignett as best man. ${ }^{8}$ After a honeymoon in Stratford-uponAvon, they returned to Benson's company, to hone their skills and rise through the ranks to more significant roles. Oscar's weekly wage at this time was three times more than Lily's, but that was to change considerably over time as their marriage facilitated their development as a theatrical duo and a partnership brand that turned them into actor-managers of renown, celebrity and considerable wealth.

The 1900 season of Benson's company at London's Lyceum Theatre propelled both their careers to unexpected heights. Lily played Helena in A Midsummer Night's Dream and Olivia in Twelfth Night to very favourable reception, ${ }^{9}$ leading to an invitation from Herbert Beerbohm Tree to play Viola in Twelfth Night in 1901. Viola, disguised as Cesario, helped to define Brayton as an actress. Her performance both conformed to and defied the gender expectations of the time, and captured critical attention. A long section of the unattributed opening night review, for instance, in the Illustrated London News was devoted purely to Brayton:

Unheralded and unsung, the young lady, who filled a subsidiary position in "Henry V." at the Lyceum twelve months ago, at one bound came forward and carried the house along with her. We do not say that Viola is a part which tries an actress to the full. It would be almost a cruelty for so young and graceful a lady as Miss Brayton to be handicapped on her first appearance by demands which can only justly be made on a fullblown tragedy queen. But the sympathy, the tenderness, the womanliness, the charm of a soft and gracious personality, added to beautifully clear-cut elocution, made the new-comer "safe" in the first five minutes. Of no commanding physique, yet endowed with convincing earnestness and simplicity of method, Miss Brayton made Viola what she rarely is - plausible both as girl and boy. Every word she uttered reached the furthermost corner of the theatre, and what lent chief charm to her work was the avoidance of point-making and the conventional simpering, overdone artificialities by which heroines masquerading in male clothes frequently make themselves ridiculous. The value of this performance cannot well be exaggerated. It lends to "Twelfth Night" a sustained and continued ray of brightness. At the risk of appearing to praise too highly - it is never kind to do that, because the limits of an actress's possible achievement cannot be set out so early in her career - we would express extreme pleasure at so delightful a piece of acting, studied, natural, and independent of all artifice. The calls for this lady at curtain-fall were generous and general. ${ }^{10}$

Although the reviewer tempers his description of the audience reaction to Brayton, and cautions about this being a performance of an 
actress early in her career, most of the review is taken up with analysis of her acting skills, her interpretation of the role and her impact on the contemporary stage. It also focuses on her playing with gender. Production photographs of her costume reveal a bi-gendered image, with swathes of flowing fabric in the form of a white linen shirt, lavender tunic, crimson silk hose, cap and sash replete with dagger. Although a replica of her brother Sebastian's costume, Viola's costume differed significantly from those worn by men (doublet, hose and stiff cuffs). Reading between the imagery and this extended description in the review, Brayton refrained from playing a man, in exaggeration or caricature, but truthfully played a woman with masculine attributes and designs. With her contralto voice, she was able to attenuate her femininity vocally as well, and command the stage and the house with a voice that gave her character the power

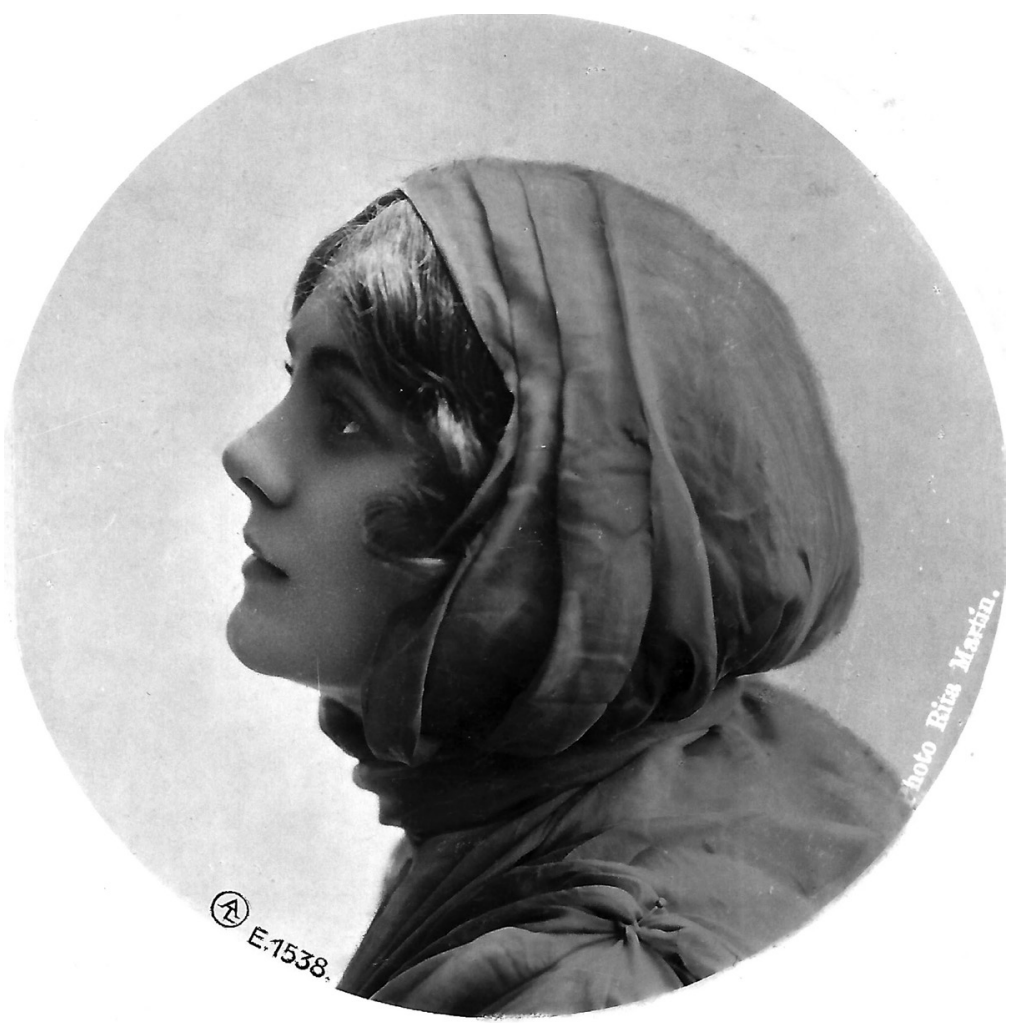

25 Lily Brayton in profile, date unknown. 
and presence of woman as man, recognisably bi-gendered, but readable as woman for all that.

The Illustrated London News was the paper of choice for the Victorian middle classes. As Jemima Kiss reports, the woodcut imagery and later photographs (by the time of Brayton's arrival on the London stage) that accompanied the text increased the consumption of news of political, social and cultural events: "It was the multimedia of its day," according to Seth Cayley: "In one sense, people didn't know before then what the rest of the world really looked like. ILN was the strongest paper of its sort and helped shape the middle class."'11 It also put faces to names for the first time for a general readership of approximately 300,000 at its height, again acting as a conduit for further consumption beyond its pages, and exciting a desire to experience the real. Such a glowing review for Lily Brayton would thus easily have caught the attention of the theatregoing public in London. The reviewer continues with a description of the impact that Brayton's performance had and was to have on ILN readers and future spectators:

Here in the finest playhouse of London, before a crowded and discriminating audience, this graceful girl, with the musical voice, made a hit - a palpable hit. Is it any marvel that the theatre casts such a glamour over the imaginative and emotional aspirant; is it any marvel that hundreds of Miss Brayton's age and sex will turn with envious admiration to this clever little woman who with no "friends at court," has come and conquered? ${ }^{12}$

Eliding actress with character, the reviewer finally and unequivocally announces the new star of the London stage.

Asche joined Beerbohm Tree's company a year later and the couple grew in skill and fame, in equal measure. Mutual recognition of each other's creativity and their matching popularity propelled both their careers into theatre production. With a lease taken out on the Adelphi Theatre by fellow Bensonian Otho Stuart, and joined by other fellow Bensonians, the 'Oscar Asche-Lily Brayton Company'13 was launched in September 1904 with a repertoire of Shakespeare and contemporary poetical drama. During the three-year lease, nine productions were mounted in repertory. The first of their Shakespeare productions, The Taming of the Shrew, would be revived no fewer than five times during the lifetime of the company and it became their second most popular production of all time. Asche believed they played it more than 1,500 times (Asche, 1929: 112). There is little doubt that the success of the 
production lay in the pairing of husband and wife producers, Oscar and Lily, as Petruchio and Katharina, in an onstage duel for gender supremacy. Historically the production is remembered for the inclusion of the twenty-minute Induction scene ${ }^{14}$ in which Asche played Christopher Sly, a character that would act as a template for his many orientalist characterisations to come. The popularity of the production lay in the style in which they chose to perform. As Asche gleefully admitted, 'We played it as a jolly farce and it always went with a scream' (Asche, 1929: 112 ).

Contemporary critics and historians confirm the approach and its popular success. The review in the Illustrated London News focused on Asche's masculinity (for which he had already made a name in the West End): 'Mr Asche's reading of the shrew-tamer is one that lays stress on brutal, masculine force, which is no mask with him - scarcely even policy, but first instinct; and with the actor's robust physique and sonorous voice such a Petruchio proves irresistible. ${ }^{15}$ If Asche's masculinity was to prove irresistible, then it was, according to Veronica Kelly, framed as the drunkard Sly's fantasy, in which he rendered 'feats of woman-taming unlikely outside the brilliant play world of Renaissance Italy' (Kelly, 2006: 43) and thus the transformation of Katharina highly unlikely. Hesketh Pearson remembered how Brayton was credited as much as her husband for the production's success:

Lily Brayton was incomparably the best Katharina of her time, and both of them jumped at a bound to the front of their profession. It was a breathless, knockabout, rampageous show, played on broadly farcical lines, and the audiences rocked with laughter. Wherever it was performed it raised the roof [...] (Pearson, 1950: 66)

Looking back on the production, Claude McKay wrote of how 'the pair took London by storm', and noted Brayton's performance as being equally memorable. ${ }^{16}$ They were both lauded for their voice and movement skills, a success that was due in no small part to Brayton being the first British actress to use the technique of F. M. Alexander who had arrived in London just before the play opened. Having been cured of laryngitis, she would return to Alexander numerous times during the season at the Adelphi, and credited him with improving her technique and stamina as an actor. She and Oscar were such enthusiasts of the technique that they introduced their friends to Alexander and were primarily responsible for the huge influence of the 'Alexander technique' on British theatre training that persists today. ${ }^{17}$ 
Brayton's Katharina was also renowned for her five costumes, challenging gender norms visually to match her physicalised performance. Veronica Kelly describes the first - a green hunting dress conveying 'a cross-gender vestimentary repertoire of leather and masculine fabrics pierced by slashes and cross lacings, topped by a piratical scarf and masculine hat, the whole adorned with buckled belt, daggers horns and glinting spiked metal' (Kelly, 2006: 44-5). Every detail of the costume suggested a woman of action, equal in every way to Petruchio. On their first Australian tour in 1909-10 they were presented with a pair of greyhounds as a gift, a nod to Asche's hobby of dog-breeding and racing, but it was Brayton as Katharina who appeared on stage with the dogs, and would do so in subsequent revivals of the production back in London. Audiences who followed the by-now celebrity couple's relationship in the weekly magazines and papers would well know that the dogs were primarily Asche's passion, and the sight of Brayton with the dogs on stage, and not Asche, would have caused much amusement. Audiences would also have read this usurpation of her husband's hobby as another sign and layer of Katharina's gender battle on stage. The Illustrated London News review of the production was very clear as to who won the battles of the sexes:

Principal honours, without a doubt, fall to Miss Lily Brayton, whose Katharina is an even finer piece of work than her Viola [...] Mr. Asche gives the impression of 'how to tame a shrew,' yet the manner of his taming is likely to win the sympathy of the audience for the shrew herself. $^{18}$

The playing together of the two performances, brute strength and spiritedness, as a husband and wife team resonated with the already popular battles of the sexes in musical comedies. As the revivals mounted up in the ensuing years against a background of suffragism in England and anxieties about Empire and the threat of war, this production provided a vehicle for a not too political nod to the realities of gender inequality. Lily Brayton did not go as far as to represent the 'New Woman' in the theatre, and offstage she declined politely any association with the Actresses' Franchise League. ${ }^{19}$ However, as we shall see, she found a way of playing her gender in both English and Orientalised contexts as Veronica Kelly describes, 'according to the contemporary understanding of the "womanly" heroines of Shakespeare who variously projected fortitude, shrewd enterprise, good sense, and moral charisma' (Kelly, 2006: 46). This was precisely the role she played offstage, too, deferring 
to her husband in public, while taking more of a lead as producer and in the conscious presentation of self onstage. For the next three decades the company title gave equal billing to both Lily and Oscar, though his name almost always came first. However, as we shall see, with all the qualities Kelly describes regarding her onstage persona, Lily's shrewdness in the business of theatre would come to the fore, and eventually the order of the names would be swapped in the billing as the power dynamics of the celebrity couple shifted.

If Shakespeare's heroines were to make her name and reputation, it was Brayton's many roles as the 'oriental woman' that were to bring her unprecedented fame, further agency in the production process, a directly executive role in the management of the Asche-Brayton Company, and ultimately wealth and security in the precarious West End business of theatre in a decade of war and its aftermath. Brayton made her first appearance as an 'oriental woman' in Beerbohm Tree's touring version of his production of David Belasco's play The Darling of the Gods which had its London premiere in 1903. Asche describes in his autobiography his first encounter with his wife as an 'oriental woman': 'I remember arriving home very late one night, or morning, after a long rehearsal. I went into the bedroom, and there on the bed, sound asleep, with a wonderful headdress, a Japanese girl. It was Lil' (Asche, 1929: 105-6). Orientalism on the London stage by that time was extremely fashionable, particularly in musical comedy from the late 188 os onwards. It reached its apogee in the Edwardian period, with its excuse for an exoticism particularly in costume design, stage spectacle and plots of English woes and travails mapped on to 'oriental' characterisations and situations. The Orient of Edwardian theatrical orientalism was a halfway place sited between the exoticism of a desire for an imaginary Other (in terms of sex, religion and culture) and a profound anxiety, provoked by the reality of an aggressive late-Victorian New Imperialism, and fear of the Other (in terms of war, death and civilisation). While British melodrama of the late nineteenth century played out the fears and anxieties of the home nation, the stages of musical comedy and pantomime were filled with charming plots, recognisable characters thinly disguised as foreign, and imaginative decoration to delight the senses.

In the first seven years of the Asche-Brayton Company, oriental characters did not feature at all. It was upon their return from the company's first Australian tour (1909-10) that everything changed. Although Asche acknowledged direct experience of other cultures on their journeys back and forth to Australia as being a source of influence 
for the change of direction, it was primarily the vogue for orientalism in the theatre at the time that should be credited. Two examples of contemporary European theatre had the most influence on the company's change of direction, as they both moved the vogue of orientalism higher up the cultural scale. First was the visit of Diaghilev's Ballets Russes to the London Coliseum in 1910 dancing Rimsky-Korsakov's Scheherazade, designed by Léon Bakst and choreographed by Michel Fokine. It was most memorable for an orgiastic Bacchanale scene, which, along with its choreographer, would feature ultimately on the Asche-Brayton stage. The second production that set the critics alight was the Berlin Deutsches Theater's production of Sumurun, a modernist and orientalist dumbshow (or pantomime as it was described at the time) directed by Max Reinhardt that also played at the Coliseum in $1911 .{ }^{20}$

Asche jumped on the trend and set to work immediately obtaining the English and Australian rights to Edward Knoblauch's play Kismet (formerly 'Hajj's Hour'), and crafted for it a dramaturgy that he knew well from his version of The Taming of the Shrew. He set himself up as the Sly figure Hajj, whose vision of the Orient appeared, introducing a bazaar scene for spectacle and a harem bathing scene similar to that of the Ballets Russes. In terms of production, Asche was experimenting with lighting to an even greater degree than is evidenced in the prompt books of his earlier Shakespeare productions. Brayton meanwhile, adjusted to the new vogue, as well as to the possibilities of Asche's lighting effects, with fabrics that created 'dazzling, glamorous magic'. ${ }^{21}$ She played the role of Marsinah, daughter to Asche's less than noble beggar Hajj, who was in a secret relationship with the Caliph, but whom Hajj wished to sell to the Wazir. Wrenched from one suitor to another by her father, audiences would not have failed to see the comedy of the couple as father and daughter rather than as husband and wife. Though Hajj was punished for his deeds at the end, Marsinah achieved a social elevation marked by a clothing change, a fact that would not be lost on a contemporary audience.

Though an 'Arabian Nights' morality tale, Kismet spoke clearly of the English class system, thereby allowing Brayton's second 'oriental woman' to climb socially, and transgress the stereotype of the veiled virgin to become a woman of agency in a strict gender hierarchy and ultimately a woman of substance. But there is evidence, too, of the fashion icon that Brayton had become, as her costumes liberated her from strict English conventions and permitted the revealing of more flesh. Costumiers B. J. Simmons \& Co., who realised Percy Anderson's designs 
under the supervision of Brayton, made similar costumes available to hire to the public subsequently, for the fancy-dress balls that were all the rage at the time in middle-class society: 'Since "Sumurun" and "Kismet" first showed the dancing world the picturesqueness and freedom of the Persian dress, ladies of the harem, sheiks and caliphs have littered the floor of every fancy-dress ball. All Suburbia has a yashmak... ${ }^{22}$ In fashion writer Mrs Aria's costume handbook of 1906, there is a clear indication that the veiled woman of the Orient acted as signifier of an imagined, unveiled one. ${ }^{23}$ Thus the costume designs for Brayton and the many dancers in the production veiled the flesh in flowing fabrics that Asche's lighting effects then unmasked.

Between the success of Kismet in 1911 and the defining period of the Asche-Brayton Company from 1916 to 1922, Lily Brayton was to portray three further characters of different nationalities in similar manner: the eponymous heroine in Shakespeare's Antony and Cleopatra, in a production that opened in Melbourne's Theatre Royal in 1913; upon their return to London from Australia via a stopover tour of South Africa, a Zulu princess in the eponymous Mameena, an adaptation by Asche of Henry Rider Haggard's recently published novel Child of Storm (Globe, 1914); and finally a Spanish Juanita in a pirate play The Spanish Main (Apollo, 1915) penned by Asche under a pseudonym. ${ }^{24}$

Although Brayton's name was in the original registered company title (the Asche-Brayton Syndicate Limited) which was set up for their first season at His Majesty's in 1907, she did not start off as an investor or director. ${ }^{25}$ However, her succession of leading roles and her offstage performances with her husband in acting, sporting, charity and royal circles would suggest that she played a major role in the success of the brand, if not the company at the time. However, a number of interviews with Australian journalists while on tour, as Veronica Kelly has revealed, point to Brayton's active role in the decision-making processes of theatrical production, particularly in terms of design. While her husband continued to experiment with lighting, as evidenced in the extant prompt books to his Shakespeare productions and in his autobiography, Lily Brayton began to reveal her role in the dressing and re-dressing of the productions, notably with an eye to the signification of clothes in terms of how they were read socially, but also significantly how they operated as part of an organic scenographic process.

The Melbourne weekly Table Talk, an illustrated magazine with an interest in public figures and their fashion and social engagements, was the perfect vehicle for Brayton to reveal the signification of her work 
and relationship with clothes both on and off the stage. During the first two Australian tours on which Brayton accompanied Asche, Table Talk conducted a series of interviews that specifically referred to her design role in the productions, though this was not credited in any advertising, playbills or theatre programmes. In a 1910 interview, prior to the opening of Kismet and the beginning of the fantasy orientalist design spree by the company, Brayton revealed: 'Nowadays not only are the dresses for our productions made under my direction, but I took premises in London where the bulk of them were made, and staffed it so that the workers were directly responsible to me. ${ }^{26}$ She also reveals a hand in design:

The great difficulty I find in dressing our plays in the character of the period is in getting the colors. In several instances we have been quite unable to get just the shade that was required, and I have had to get the cloth specially woven, after a great deal of experimenting with dyes. This was done with the 'rainbow' dress in 'Othello'.

But she also reveals that dresses are not her only interest in terms of stage design:

I work morning, noon and night, in the theatre, always pottering about at the dresses, the furniture, or something. Of course, my interest in our productions does not begin and end with studying my part and playing it. I look upon the wardrobes as my own special department, and supervised the re-dressing of the plays produced in Australia[....$^{27}$

And specifically in terms of stage design she recalls an anecdote of finding by accident the table for the design of Count Hannibal (1910). In a later interview with the same magazine, she specifically details her precise role in the design process: 'Yes, I design some of the dresses, and always supervise them, the color harmonies and blendings, and that kind of thing, but usually we have an expert to design, to have them historically correct. ${ }^{28}$

The interviews she gave in Australia, as Veronica Kelly has noted (Kelly, 2006: 39-59), provide details of Lily Brayton's views on fashion as well as her knowledge of the production processes of theatre. Here Brayton revealed how she worked together with her husband, articulating and situating her own contribution within their productions. Her taste for the medieval in terms of the shape of dresses indicates how her costumes, which do not specifically reveal the shape of her body, have been read as bi- or transgendered. Yet her talk of the possibilities of modern colour in terms of dyes, of brightness and illumination, and of 


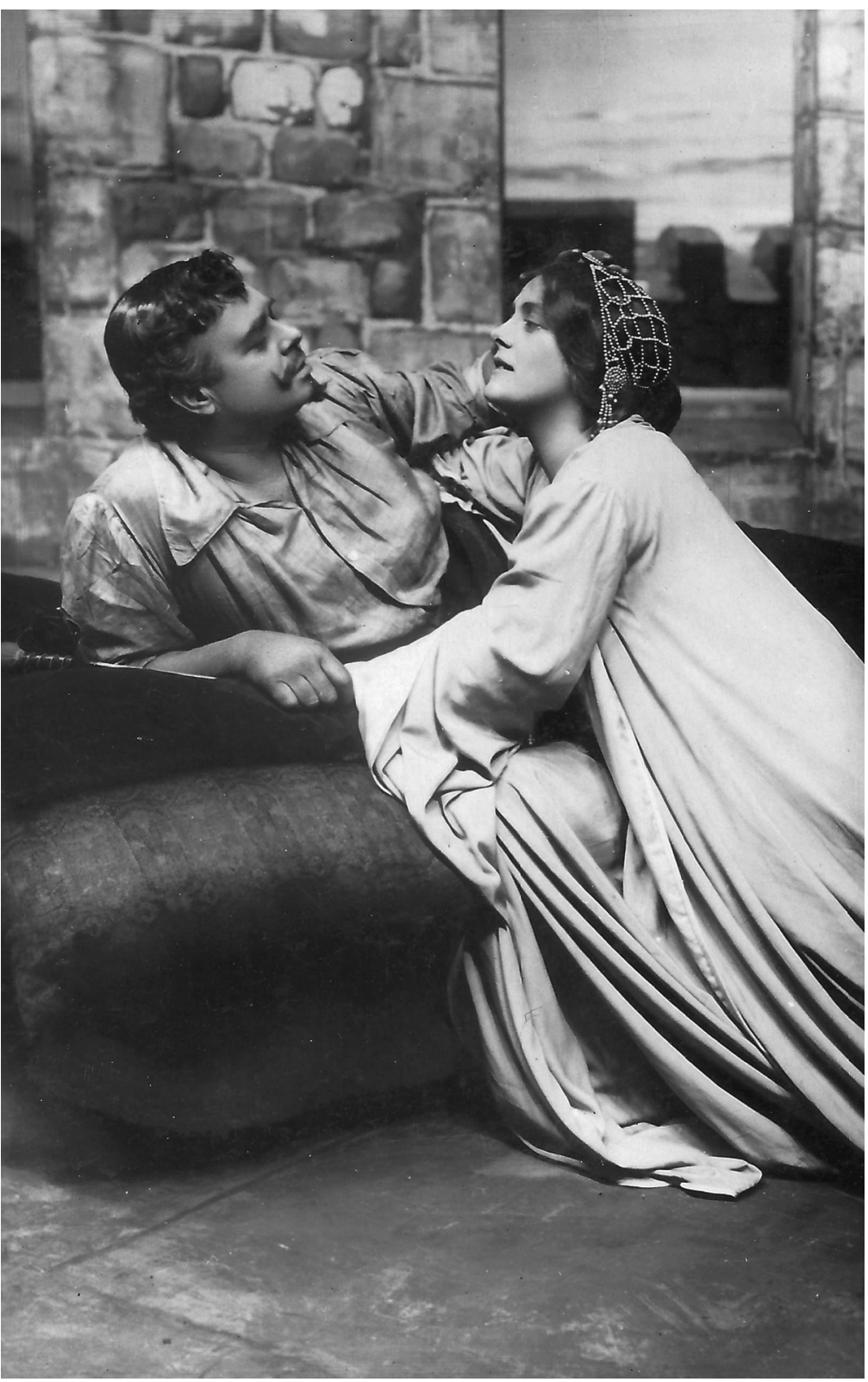

26 Lily Brayton and Oscar Asche in Hannibal, 1910. 
how fabrics both absorb and reflect light are completely of an equal to her husband's knowledge of and experimentation with stage perspective and lighting.

Moving from purely acting to the design processes of theatrical production was a natural step for the actor-manager that Brayton had become in the pre-war period. But her role as investor in her own productions occurred during the most unlikely of times, the First World War and after. The production in question was Chu Chin Chow, an 'Arabian Nights'- inspired tale based on Ali Baba and the Forty Thieves, penned by Asche. Generically it fell between several stools; pantomime was at its base, much of it was in the style of musical comedy, but its tales

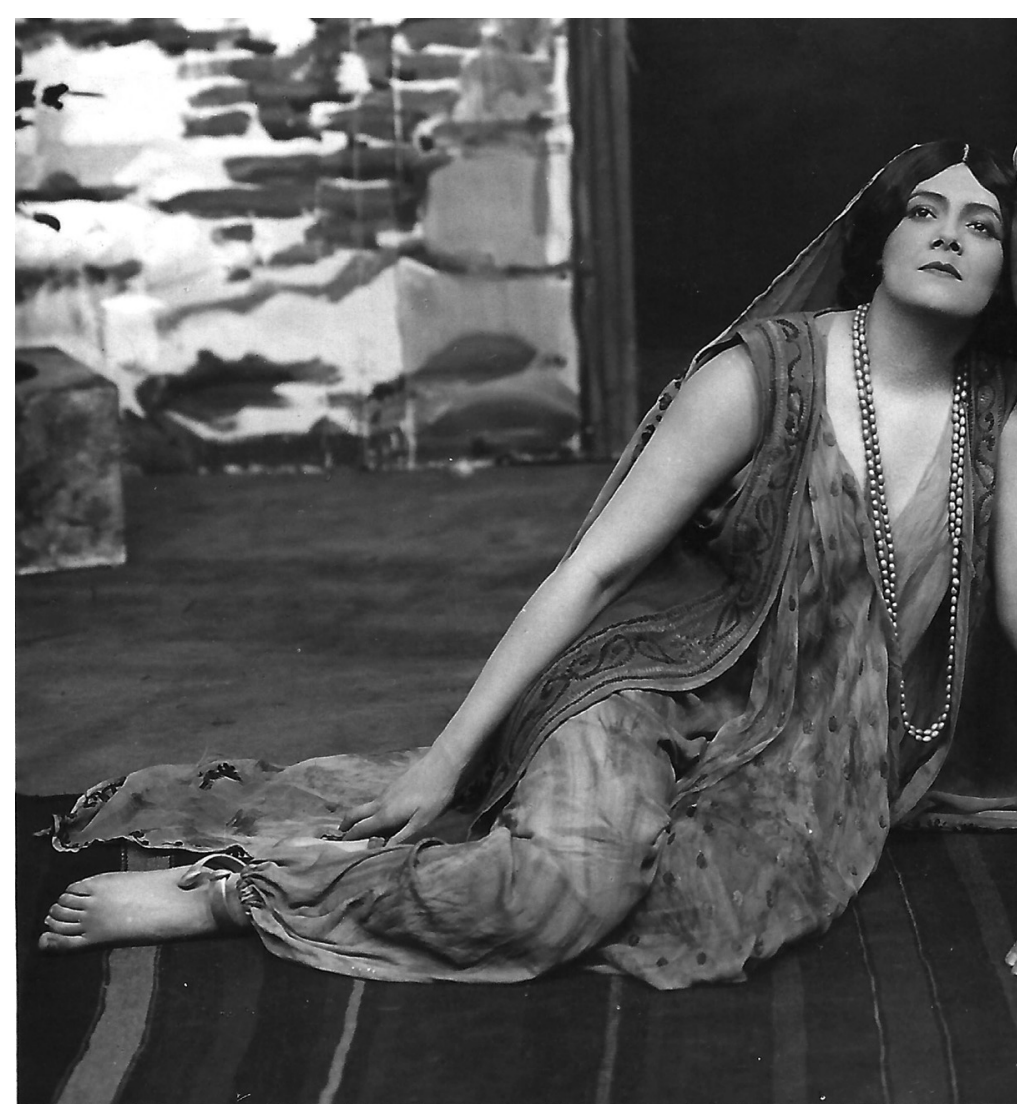

27 Lily Brayton in Kismet, 1911. 
of revenge and plot twists, and occasional patriotic jingoism, steered it into the territory of melodrama. Not only did it have the Shrew-like characterisations of Kismet, it also presented an extravagant though thinly disguised Orient that spoke to the anxieties and desires of a nation at war. Further, it responded to the course of the war with scene revisions, additional songs and regular re-dressings to entice a home audience, and the soldiers on leave, to return to see the show on more than one occasion.

At the outset no theatre was interested in Chu; producers of musical theatre, among them George Dance and Robert Evett, turned it down, even though Asche and Brayton had assembled around them key artistic personnel from previous successful productions (scene designer Joseph Harker, costume designer Percy Anderson and composer Frederic Norton). Asche specifically created a lead character for Brayton as an inducement for her financial investment in the production. And so Brayton invested $\mathfrak{k}_{3}$, ooo of her own money, to match the sum Henry Dana, the manager of His Majesty's Theatre, invested on Herbert Beerbohm Tree's behalf, in a syndicate called Eastale Limited (Asche, 1929: 161). The syndicate, according to Asche, was made up of only two shareholders, Brayton and Beerbohm Tree, who held 50 per cent of the share capital each. Further, Asche signed over 50 per cent of the author's royalties to his composer Norton, while the remaining 50 per cent were assigned to Brayton, in return for a personal loan of $£ 500$. The contractual arrangements point to how Asche was already indebted financially to Brayton, both in personal and professional capacities. Given that no production had ever matched the financial targets for the pay-out of royalties on the London stage, Asche, unlike Brayton, was prepared to work in the show, for up to ten performances a week, for a simple actor's fee. Nevertheless, Asche earned a considerable sum from this contract (over $£ 200,000$ ), despite his lack of finances at the beginning. Meanwhile, Brayton was contracted to earn one of the largest returns on an investment in British theatre. The new syndicate was not credited on any publicity and the theatre advertising for Chu heralded the 'Oscar Asche Lily Brayton Season', thus continuing the brand of the celebrity couple, and masking the contractual inequity between the two. But at the beginning of the most successful period in the couple's career, only Brayton had the financial capital to show for her celebrity as an actor, as Asche had already begun to squander his earnings on lavish parties and gambling. The dynamics of the duo were shifting through their differing attitudes to money. Chu Chin Chow opened in His Majesty's Theatre on 31 August 
1916 and ran for five years, 2,238 performances and a record box office income of nearly three and a half million pounds. Unlike Brayton, Asche spent the money as fast as he earned it. ${ }^{29}$

Throughout the long run, Brayton's name continued to remain uncredited for her work on the production, apart from her acting role. However, Chu Chin Chow saw the culmination of the pair's experimentation with fabric and colour to the point where it became the most talked-about show of its generation, principally because of its exotic and highly revealing dresses, which were overhauled every six months. Photos of the dressing and re-dressings appeared in society magazines such as Tatler, to whet the appetite for audiences to return. Lucinda Gosling points out the complicity between the society magazine editors and the production: "Very suitable for the sultry climate of Baghdad", reported Tatler in September 1917, with a palpable leer when it featured six photos of the latest designs' (Gosling, 2014: 202-3).

Like those society magazines, $\mathrm{Chu}$ Chin Chow offered escapism from the war, while barely disguising the scenes of Old Baghdad in the fight for justice against a common enemy. Popular songs in the show became emblematic of the war effort, particularly 'The Robbers' March', ironically repositioning the forty thieves to reflect the heroics of the British Army. But it was the celebrations of Armistice Day, 11 November 1918, that were to conjoin the production unashamedly with the nation's war effort. A new scene called 'The Allies and the Dominions' was included, featuring a procession of the chorus personifying Britain's allies and dominions, to the tune of 'Rule Britannia'. The procession fanned out on to the stage and the performers took up positions around a gap. That gap was to be filled by none other than Lily Brayton, dressed up as the female personification of the nation, Britannia, letting fly a white dove to complete the picture. Audiences were ecstatic, and were spurred on by the appearance of Asche as John Bull who made a victory speech to cement in everyone's mind the production's patriotism. This imagery of an assumptive pseudo-royal couple lived on in the production for six months after the Armistice, providing for audiences a repeatedly clear image of Brayton as the very embodiment of nation. Offstage she compounded the image with highly publicised charity work as a direct contribution to the war effort. National sentiment was at its highest, and so too was the popular acclaim of the actress, whose Britannia costume, replacing the scanty clothes of old Baghdad, reminded audiences that this production was a British representation of an Orient of Empire, though one of the often licentious imagination. But it was also 
a production that had earned the right to mark and celebrate a national military triumph with the nation's iconic female figurehead at the helm.

His Majesty's Theatre's publicity machine made much of the longrunning success of Chu Chin Chow, especially when the final performances were announced in 1921, increasing demand for tickets to an unprecedented level, such was the extent of the myth and lore surrounding the production in the public imagination, particularly its role in defending and celebrating nation both before and after the Armistice. Asche had meanwhile penned a new musical, entitled Mecca, scheduled to take over from Chu at His Majesty's, a musical more spectacular and more controversial. It had been produced by Morris Gest and had been a hit in New York in 1920. ${ }^{30}$ However, in London the production was threatened with censorship by the Lord Chamberlain's Office, which had to respond to Daily Mail readers' letters and conservative Christians objecting to the increasing state of undress of the actors on Asche's stage in Chu. Further, a Muslim cleric, Mustapha Khan, objected to the Lord Chamberlain's office's licensing of the play on the grounds of religious offence. ${ }^{31}$ With a compromise solution of a name change, and some minor amendments to the script, the newly titled Cairo replaced Chu on the stage on 15 October 1921.

By this time, with huge income from the American rights for Mecca, the American and Australian stage rights for $\mathrm{Chu}$, and indeed its film rights, as well as having directed two highly successful musicals at Daly's Theatre in London, ${ }^{32}$ Asche's finances had never been healthier. He had already purchased a country retreat, Sugley Farm in Gloucestershire, a purchase that would become associated with his financial and personal demise. So after a long hiatus in which Brayton's wealth had superseded his own, Asche was ready to invest once more in theatre. The AscheBrayton couple re-emerged with Cairo in a new syndicate and an investment of $£ 5,000$ and 25 per cent shares each, with the other half of the finance put up by His Majesty's Theatre's new lessees, George Grossmith and J. A. E. Malone. ${ }^{33}$ But this time there were also a number of notable changes in the credits that alert us to Lily Brayton's position both in the syndicate and the production process, which was revealed for the first time in the English press. In the Play Pictorial the credits run as follows:

Mime by Oscar Asche. Music by Percy Fletcher.

The Play Produced by Oscar Asche.

General scheme of Decoration under the personal supervision of LILY BRAYTON

LILY BRAYTON and OSCAR ASCHE's Season. ${ }^{34}$ 
Note how Brayton is credited separately from Asche as producer, and her credit with supervising the 'decoration' confirms what Brayton had been saying to Australian journalists over a decade earlier. Note, too, that Lily's name comes before Oscar's for the first time. There is no evidence to indicate why this came to pass, though the Play Pictorial makes mention of the precise role that Brayton played in the 'decoration', or, rather, the acknowledgement that Asche's all-encompassing role as producer was being unravelled: 'It is true Mr. Asche has had the assistance of able experts in their respective spheres of occupation. Miss Lily Brayton with her womanly sense of decorative appropriateness. ${ }^{35}$ This was not necessarily news to readers; nevertheless the placing of Brayton's name before Asche's in terms of the 'season' at His Majesty's must have been striking. Until now they had always worked under the umbrella title of the Oscar Asche-Lily Brayton Company, until Chu when the syndicate without Asche was referred to as 'The Oscar Asche Lily Brayton Season'. Since the Asche-Brayton theatrical partnership by this time had become a successful brand name, it points to a tectonic shift in their relationship that was reflected in Asche's fewer appearances onstage in Cairo, his increasing weight through a lavish lifestyle, his financial losses at his newly acquired farm and rumours of extra-marital affairs.

After 267 performances Cairo was taken off the stage unexpectedly on 2 June 1922, though box office returns were reported to be good, and Asche said the production made a profit of $£ 12$,000 (Asche, 1929: 174). Asche set off to his native Australia on a tour hastily arranged by His Majesty's theatre manager and fellow former-Bensonian Carl Leyel, without Brayton for the first time. The sudden departure of Asche and the disappearance of Brayton from both British theatre and public life was unexplained and inexplicable. Their separation was to be permanent, and the couple would have no further impact on the London stage.

Pre-empting the number one question of Brayton's absence when he reached Australia, Asche was not shy in informing journalists of the reason, ${ }^{36}$ and even had tour producer J. C. Williamson point out the absence in the souvenir programme that accompanied Cairo: 'but for the urgent necessity of Lily Brayton taking a long rest from the strenuous work of several years in "Chu Chin Chow" and "Cairo", the latter piece would probably have still been running in London, and Oscar Asche would not now be with us again'. ${ }^{37}$ Apart from a reference to Brayton suffering a nervous breakdown, as reported in Melbourne's Argus, ${ }^{38}$ the precise details of the demise of the production and the celebrity couple were never fully exposed. Later at his bankruptcy trial in October 1926, 
when questioned by two barristers, Asche revealed that he had been having an affair with a chorus girl, Marguerite Martini, from approximately March $1921{ }^{39}$ When Lily discovered the affair in May 1922, she refused to act with him onstage and threatened to name the chorus girl, who was half his age, as co-respondent in a very public divorce. $\mathrm{He}$ confirmed newspaper reports that Lily had suffered a nervous breakdown because of the revelation. He also claimed to have signed over his Gloucestershire farm to Martini, a fact that, if true, surely should have ended the marriage for good. But he kept that to himself at the time, and departed with some of the costume stock from the show, and some of the actors, having removed his effects from Brayton's house.

Brayton politely had Martini removed from Sugley Farm shortly afterwards, and Martini followed Asche to Australia a few months later, joined Williamson's company while on tour and appeared in minor acting roles. Two years later she returned to England with Asche on the same ship. The new couple moved back to Sugley Farm, had a child ${ }^{40}$ and ran up even more debts. Two years further on, in 1926, with hardly any income during that time, Asche was declared bankrupt. He managed to hold on to the farm, despite bankruptcy, by suspiciously producing two unverified documents at his hearing; one dated two days before his departure signing over the farm to Martini, and the second, typed by the chorus girls in Australia, leasing the farm back from Martini to Asche for $£_{5}$ per week. Asche and Martini set up a company, the Oscar Asche Greyhound Association, retained the house and grounds, rented out the land, but only filed accounts for 1928 and 1929. Thereafter the company ceased trading and Lloyds Bank called in the mortgage. ${ }^{41}$

But before all this, and though they remained estranged in marriage, Brayton reconciled with Asche to form a new syndicate, Asche Brayton Productions Ltd, to present The Good Old Days at the Gaiety Theatre in $1925 .{ }^{42}$ Brayton invested $£ 1,500$ of her own money out of $£ 10$,ooo raised. However, she lost the entire sum, as the production only lasted for thirty-seven performances. According to Asche's autobiography, an organised protest by disgruntled Gaiety chorus members who had not been hired for the production disrupted the opening night. Reviews generally were favourable, but the timing of the production was unfortunate, opening the week before Remembrance Day, and followed by the death of Queen Alexandra. Although this was the only play produced by the company, the pair continued their professional relationship. Brayton also co-produced her husband's last orientalist spectacle, Kong, at the Cambridge Theatre in 1931, but this only lasted for twenty performances, 
so unfashionable was the form by then. Why did Brayton continue the professional relationship with Asche, given his profligacy and infidelity? It is highly probable that Brayton knew nothing of the details of Asche's defence in the bankruptcy hearing or of the precise details of his affair and its duplicitous legal machinations, given her personal investment in their post-separation productions. Asche's 1929 autobiography revealed none of this. As a woman of considerable means in her own right, and separate bank accounts and property, Brayton never filed for divorce, and she remained on good terms with her husband in his final years.

Brayton did return to the stage one final time, ten years after she left it, to reprise her role as Portia in Shakespeare's Julius Caesar at His Majesty's in 1932, again under the Asche-Brayton brand, though Asche was no longer leading man material and played Casca. While critics praised Brayton's return to the stage and indeed her performance, the production was generally criticised for being nostalgic and outmoded, and signalled how out of touch Asche and Brayton as producers had become. Yet, as evidenced in the souvenir programme for the production, this revival was a clear attempt by both of them to salvage their reputation for posterity, as it featured single-page and separate acting profiles of the two actors, with their Shakespearean roles only as credits; nowhere in the official material is any mention of the orientalist roles and productions through which they had become hugely popular and financially successful. With only sixty-four performances, the impact of this reputation-saving device was negligible, and Brayton retired finally to the country.

Although Asche continued to have a sporadic career in the theatres of others, dabbled in cinema, and wrote novels and an autobiography, his career was finally over in 1934. Apart from the two years he spent in Australia (1922-24), Brayton never estranged herself from Asche, despite his many personal failings. Determined to keep in close contact with him, she rented for him a cottage called Endways, appropriately named for his last days, beside her new home in Bisham, near Marlow. While Brayton lived in The Thatched Cottage with her long-time dresser and companion Emily Mabel Davis, Asche divided his time between Endways, even becoming a member of the Marlow Operatic Society, and Marguerite Martini and their daughter in Maida Vale. ${ }^{43}$ Asche died alone in Endways in 1936 at the age of 65, leaving a total of £20 16s 4d. The filed recipient was Rose Marguerite Martin (a.k.a Martini). ${ }^{44}$

Lily Brayton remarried two years later, to Douglas Chalmers Watson, a Scottish doctor, with whom she lived for the next ten years. After his death in 1948 she bought a house in Dawlish in Devon and lived there 
with her former dresser, along with her sister Agnes and family. She died in 1953 , a very rich widow twice over; ${ }^{45}$ notably, however, she willed her ashes be buried in the same grave as Oscar in Bisham, reuniting the duo who had taken London by storm fifty years earlier. The epitaph under her name on the headstone quotes Shakespeare's sonnet 18: 'thy eternal summer shall not fade', and her name is recorded there for posterity as Asche's 'wife', though the marriage had broken down some thirty years earlier. However, their theatrical legacy as a couple did not survive beyond the grave.

Just as her career abruptly stopped, so, too, did her reputation as an actress, and if she was remembered at all in published reminiscences and histories, it was mostly for being married to an actor whose life imploded professionally, financially and personally. But Brayton ought to be remembered not only for her many positive and successful images of women on both classical and popular stages, but also as a creative producer whom the times and social conventions regarding gender in the theatre nearly erased from view. Historically, Asche is barely remembered, primarily because of his drift to populist entertainment and his sudden fall from grace, but he still earns a place because of his visible trace as author of the longest-running musical on the London stage, a record that lasted until $1956 .{ }^{46} \mathrm{He}$ is also remembered because he made sure that he was, by penning an autobiography in his later fallow years. But Lily Brayton remained only in the imagination of the generation who knew her with popular affection in her roles from Katharina to Britannia. Never associated with modernism in theatre or the 'New Woman' in drama, Brayton's contribution to twentieth-century British theatre has been consigned historically to that of the 'subaltern'. However, the shift in power dynamics from Asche to Brayton, signified by the change of name and the records of their company for their last major success (Cairo), and corroborated by them both in their self-presentation offstage, indicates that Lily Brayton was far more than a stage 'beauty' of populist entertainment, or even a 'marriage partner'; she was a highly skilled and both critically and commercially successful actor, scenographer, producer, investor and manager - a theatre maker in every sense.

\section{Notes}

1 Asche, however, consistently acknowledged throughout their partnership the prominent role Brayton played in their productions beyond what was visible on stage. 
2 http://www.npg.org.uk/collections/search/person/mpoo544/lily-brayton (accessed 1 July 2016).

3 In Stoney Lane Brayton's neighbours included not only a retired grocer and a schoolmistress, but also a coal miner, laundress, church keeper, calico weaver, factory operative and a colliery carpenter. 1891 Census for the Administrative County of Lancaster, Parish of Hindley, Ecclesiastical Parish of St Peter's.

4 'A Chat with Miss Lily Brayton', Wigan Observer, 27 November 1901.

5 'The Interviewer: Miss Lily Brayton in Private Life', Table Talk, 12 August 1909, p. 17.

6 They remained close throughout Brayton's career. Agnes lived with Brayton and Asche in London for a time, and later, when Brayton had twice been widowed, Agnes and her family moved in with Lily in Devon in her final years.

7 There are conflicting reports of the birth date of her husband Oscar, a conflict deriving from subsequent submissions of his age in the 1901 and 1911 censuses that indicate a lesser gap. In fact, he reduced both their ages on both census forms. On the headstone of their grave, Oscar's birth year is 1872 . His birth certificate, however, states 24 July 1871.

8 Marriage Records of St Peter's Church, in the Parish of Hindley, in the County of Lancashire, No. 298.

9 She was described as 'a star of the future' for her performance as Helena in a review of A Midsummer Night's Dream in the Standard, 23 February 1900.

10 Unattributed review of Twelfth Night, Illustrated London News, 6 February 1901.

11 Jemima Kiss, 'Illustrated London News Goes Online', Guardian, 15 April 2010, https:/www.theguardian.com/media/2010/apr/15/illustrated-londonnews-archive-online (accessed 20 June 2016).

12 Illustrated London News, 6 February 1901.

13 This was the beginning of the Asche-Brayton brand. At this stage neither invested in their own productions.

14 According to the prompt book, the scene began at $8.20 \mathrm{pm}$ and finished at $8.40 \mathrm{pm}$. Shakespeare Centre Library, Stratford-upon-Avon.

15 Illustrated London News, 10 December 1904, p. 854.

16 Claude McKay, 'How Oscar Asche Spent a Fortune', Sun-Herald [Sydney], 19 October 1952.

17 Letter from Lily Brayton to F. M. Alexander, 26 January 1906 (cited in Bloch, 2004: 56. See also 52, 58.)

18 Illustrated London News, undated press cutting, V\&A production file.

19 Invited by fellow actress (and activist) Winifred Mayo to participate in a conference of the Actresses' Franchise League at Memorial Hall in London on 14 February 1914, and to join a demonstration in Trafalgar Square, Lily Brayton was unavailable. See letter from Winifred Mayo to fellow actress and activist 
Maud Arncliffe Sennett, London, 23 January 1914, in 'A Collection of press cuttings, pamphlets, leaflets and letters mainly relating to the movement for women's suffrage in England, formed and annotated by M. Arncliffe Sennett', Vol. 25, No. 96, British Library, C.121.g.1 (cited in Hirshfield, 1985: 140). See also Naomi Paxton's chapter in this volume.

20 A contemporary reading of both productions and their effects can be found in Huntly (1912).

21 Claude McKay, 'How Oscar Asche Spent a Fortune', Sun-Herald [Sydney], 19 October 1952.

22 Unidentified press cutting, Kismet production file, Harry Ransom Humanities Research Center, University of Texas at Austin.

23 See Aria (1906: 102). For a further analysis of how this double signifier worked in Kismet, see Singleton (2004: 81-3).

24 Vasco Marenas.

25 Asche Brayton Syndicate Ltd, National Archives, Company No. 94235. The syndicate was initially intended to be called The Dramatic Enterprise Ltd, but this was struck off and replaced with the star actors' names at the last minute before registration. Its initial capital was $£ 12,000$, and no annual financial returns for the company are extant, suggesting that it was created in order to take over the running, though not the lease, of His Majesty's Theatre in 1907. It was eventually dissolved in 1917, without having traded for many years.

26 “"How I Dress Our Plays": Miss Lily Brayton and Stage Dress', Table Talk, 13 January 1910, p. 16.

27 Ibid.

28 'The Interviewer: Miss Lily Brayton in Private Life', Table Talk, 12 August 1909, p. 17.

29 At his bankruptcy hearing he divulged earning approximately $£ 200,000$ from Chu Chin Chow alone, apart from his royalties from Kismet and earnings from his other productions. Brayton's earnings must have been even greater, given that she was a 50 per cent shareholder in the syndicate.

30 Opened on 4 October 1920 at Century Theatre, transferring to the Boston Opera House in September the following year, for a month.

31 For a full description of the attempted censorship of the production, see Singleton (2010: $351-77$ ).

32 The Maid of the Mountains (1917) and A Southern Maid (1920).

33 Asche referred in his bankruptcy hearing to two syndicates being set up, one called Mecca Productions (Asche and Brayton) and the other by the lessees called Grossmith and Laudrillard Ltd. However, neither company is listed in the Companies' Office.

34 Play Pictorial, xxxix.237, 1921, p. 116.

35 Ibid.

36 'Mr Oscar Asche: Australian Season of Plays', Argus, 25 August 1922, p. 6.

37 Phil Finkelstein, 'Souvenir Edition of Oscar Asche and his Complete London 
Production of Cairo', p. 57, Cairo production file, B. J. Simmons Collection, Harry Ransom Humanities Research Center, University of Texas at Austin.

38 Argus, 25 August 1922, p. 6.

39 Rose Marguerite Martin.

40 Marguerite Asche, born 1926, Paddington, London. Mother's maiden name: Martin.

41 The Oscar Asche Greyhound Association Ltd was registered as a company, with Asche having only one share in it, but Marguerite Martini holding 80 preferential and 3,000 ordinary shares, making her the biggest shareholder. It was formally dissolved in 1932. Company No. 226808. National Archives, $\mathrm{BT}_{31 / 30070 / 226808 .}$

42 Company No. 208684, incorporated 1925. National Archives, BT31/29 $253 / 208684$.

43 In the National Probate Calendar (Index of Wills and Administrations) she was listed both as Asche and Martin, living in Bexley, Kent; she died on 18 September 1978, leaving the not inconsiderable sum of $£ 24,196$.

44 https://probatesearch.service.gov.uk (1936, p. 102).

45 Her estate was worth $£ 49,336$ and 13 shillings (equivalent to approximately 1 million pounds at 2016 values). https://probatesearch.service.gov.uk/Cal endar? surname=watson\&yearOfDeath $=1953$ \&page $=6$ \#calendar (accessed 3 September 2018).

46 It was overtaken by Salad Days at the Vaudeville Theatre in 1956.

\section{References}

Aria [Eliza (David)], Mrs (1906), Costume, Fanciful, Historical, and Theatrical. Compiled by Mrs. Aria. Illustrated by Percy Anderson, London: Macmillan.

Asche, Oscar (1929), His Life, By Himself, London: Hurst and Blackett.

Bloch, Michael (2004), F. M.: The Life of Frederick Matthias Alexander: Founder of the Alexander Technique, London, Hachette.

Carter, Huntly (1912), The New Spirit in Drama \& Art, London: Frank Palmer.

Davis, Tracy C. (2000), The Economics of the British Stage, 1800-1914, Cambridge: Cambridge University Press.

Fletcher, Chrissy (2004), A Theatrical Life: The Many Faces of Oscar Asche 1871-1936, New South Wales: Burradoo.

Gosling, Lucinda (2014), Great War Britain: The First World War at Home, Stroud: The History Press.

Hirshfield, Claire (1985), 'The Actresses' Franchise League and the Campaign for Women's Suffrage 1908-1914', Theatre Research International, 10.2, pp. 129-53.

Kelly, Veronica (2006), 'Australia's Lily Brayton: Performer and Theatre Artist', Nineteenth Century Theatre \& Film, 33.1, pp. 39-59.

Pearson, Hesketh (1950), The Last Actor-Managers, London: Methuen. 
Singleton, Brian (2004), Oscar Asche, Orientalism, and British Musical Comedy, Westport, CT: Praeger.

Singleton, Brian (2010), 'Narratives of Nostalgia: Oriental Evasions about the London Stage', in Charlotte M. Canning and Thomas Postlewait, eds, Representing the Past: Essays in Performance Historiography, Iowa City: University of Iowa Press, pp. 351-77. 